\title{
Denitrification in coastal bay sediment: regional and seasonal variation in Aarhus Bight, Denmark
}

\author{
Mikael Hjorth Jensen, Torben Kjær Andersen, Jan Sørensen \\ Department of Ecology and Genetics, University of Aarhus, Ny Munkegade, DK-8000 Aarhus C, Denmark
}

\begin{abstract}
The seasonal pattern of denitrification activity was studied in sediment from 3 stations in the Aarhus Bight, Denmark. At all 3 stations, a dramatic increase in denitrification activity was found in early spring coincident with sedimentation of the spring phytoplankton bloom. The maximum of activity was followed by declining rates in the early summer and low and relatively constant rates throughout the rest of the year. For the 3 sediments, the total range of denitrification activity was $<0.05$ to $0.5,0.05$ to 0.7 and 0.2 to $1.0 \mathrm{mmol} \mathrm{N} \mathrm{m} \mathrm{N}^{-2}$, respectively, and the total annual activity 35,70 and $180 \mathrm{mmol} \mathrm{N}$ $\mathrm{m}^{-2} \mathrm{yr}^{-1}$ Regional differences in activity were comparable to differences in organic content at the 3 stations; throughout the year, highest activities were observed in the most organic-rich sediment and lowest were observed in the relatively organic-poor sediment. Results indicate that annual denitrification may increase in response to higher nutrient load and primary production in the coastal sea.
\end{abstract}

\section{INTRODUCTION}

The increasing nitrogen loads in coastal environments (Maybeck 1982) have led to considerable interest in the marine nitrogen cycle. Denitrification in sediments has received much attention due to its role as a natural sink for combined nitrogen. During denitrification, $\mathrm{NO}_{3}^{-}$is reduced primarily to $\mathrm{N}_{2}$ und to a lesser extent to $\mathrm{N}_{2} \mathrm{O}$, both of which can escape to the atmosphere. Denitrification thus mitigates coastal nitrogen loading from terrestrial sources (e.g. Seitzinger \& Nixon 1985), and may in some cases limit coastal primary production (Boynton et al. 1980, Nixon 1981). In order to estimate the role of denitrification in coastal eutrophication, it is of prime importance to determine the temporal and regional variations of the process and to identify the regulating environmental factors.

Until recently, measurements of in situ rates of denitrification were sparse for coastal environments. A few investigations have dealt with the natural activity and local variation of denitrification in estuaries (Andersen et al. 1984, Sørensen 1984, Jørgensen \& Sørensen 1985 , Smith et al. 1985, Seitzinger 1987, Jørgensen \& Sorensen 1988 (preceding article\}) and other near-coastal environments (Seitzinger et al. 1984, Kaspar et al. 1985). Not surprisingly, a variety of denitrification patterns have been observed.
The purpose of the present investigation, which took place over 16 mo in 1985-86, was to determine the seasonal and regional variations of denitrification in a coastal bay area characterized by a significant phytoplankton bloom and rapid detritus sedimentation in early spring.

\section{MATERIALS AND METHODS}

Study area and sampling. The investigation was carried out in Aarhus Bight on the east coast of Jutland, Denmark (Fig. 1). In terms of hydrography and biological oceanography, the bight is representative of many near-coastal areas in the Kattegat, which separates the Baltic from the North Sea. In spite of the shallow water, there is often a marked stratification in the water column when low-salinity surface water from the Baltic meets saline bottom water from the North Sea. Primary production and sedimentation of organic matter are high in spring and significant $\mathrm{O}_{2}$ deficits may develop in the bottom water and sediments from spring to fall. For the present investigation, we collected water and sediment samples frequently at 3 localities in the bay: Stns 10,16 and 22, all at a water depth of $15 \mathrm{~m}$ (Fig. 1).

Temperature, salinity, and concentrations of $\mathrm{O}_{2}, \mathrm{NO}_{3}^{-}$ and $\mathrm{NO}_{2}^{-}$were determined in samples from both the 


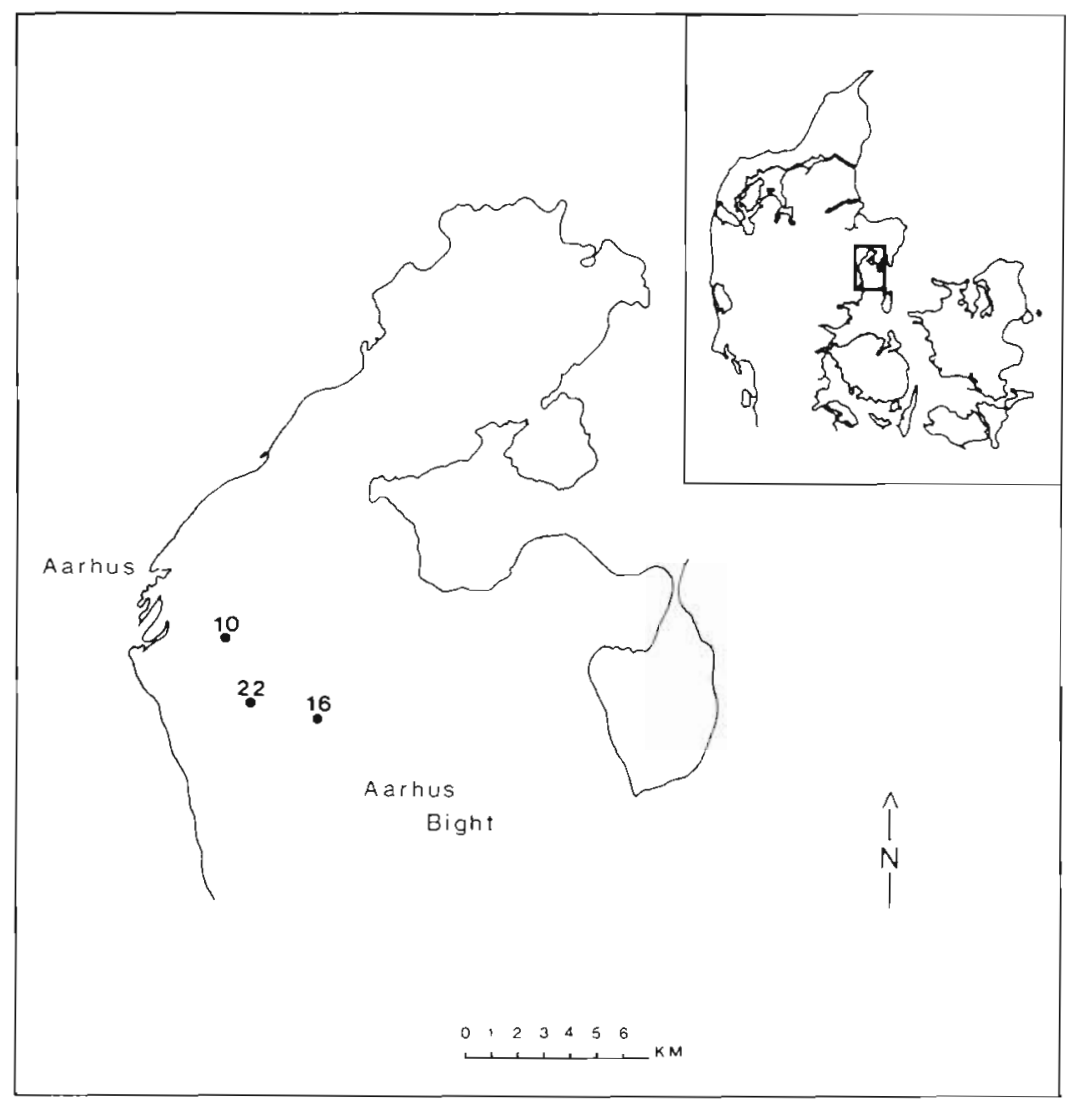

Fig. 1. Study sites in Aarhus Bight, Denmark

surface water ( $2 \mathrm{~m}$ below the surface) and the bottom water $(0.5 \mathrm{~m}$ above the sediment). On the day of sampling, a water sample taken at one of the stations was assumed to be representative for the whole sampling area.

Sediment was collected with a 'Haps' sampler which took $12.5 \mathrm{~cm}$ (i.d.) cores of the sediment (Kanneworff \& Nicolaisen 1973). From the main core, a number of smaller subcores were taken in $3.6 \mathrm{~cm}$ (i.d.) wide and $12 \mathrm{~cm}$ long acrylic tubes for determinations of density, water content, organic content, and denitrification activity in the sediment. All cores were carefully inspected and only those with an undisturbed sediment-water interface were used.

The sediment was collected at approximately monthly intervals (fortnightly in the spring period) at each of the 3 stations. The determinations of denitrification activity in the cores were initiated within few hours after sampling. Determinations of the other sediment characteristics were done the next day after storage of the cores at $3^{\circ} \mathrm{C}$.

Water and sediment chemistry. Salinity was measured potentiometrically (Conductivity Meter CDM 3, Radiometer, Copenhagen, Denmark) and a Winkler titration was performed to determine dissolved $\mathrm{O}_{2}$ concentrations (Strickland \& Parsons 1972). Water samples for $\mathrm{NO}_{3}^{-}$and $\mathrm{NO}_{2}^{-}$assays were stored frozen $\left(-20^{\circ} \mathrm{C}\right)$ in $25 \mathrm{ml}$ polyethylene vials which contained $50 \mu \mathrm{l}$ of chloroform. After thawing, the $\mathrm{NO}_{3}^{-}$and $\mathrm{NO}_{2}^{-}$concentrations were determined colorimetrically by an autoanalyser (Chemlab Instr. Ltd, Essex, England) using the method of Armstrong et al. (1967).

Duplicate determinations of density (specific gravity), water content (weight loss after $24 \mathrm{~h}$ at $105^{\circ} \mathrm{C}$ ), and organic content (ignition loss of dry samples after $3 \mathrm{~h}$ at $540^{\circ} \mathrm{C}$ ) were performed on $1 \mathrm{~cm}$ segments of the sediment to a depth of $5 \mathrm{~cm}$.

Assay of denitrification activity. The measurements of denitrification were based upon the acetylene inhibition technique (Sorensen 1978). Acetylene, which inhibits the reduction of $\mathrm{N}_{2} \mathrm{O}$ to $\mathrm{N}_{2}$, is distributed into closed sediment cores and the rate of $\mathrm{N}_{2} \mathrm{O}$ accumulation is used as a measure of denitrification. We essentially used the core design and incubation procedure of Andersen et al. (1984). A modification, by which the total $\mathrm{N}_{2} \mathrm{O}$ accumulation was determined in whole cores of $\mathrm{C}_{2} \mathrm{H}_{2}$-treated sediment, was used.

Eight sediment cores were taken for each determination of denitrification activity. The water phase above the sediment was ca $7 \mathrm{~cm}$ high $(70 \mathrm{ml}$ volume). The tubes were filled completely with bottom water from the locality and gastight acrylic caps were mounted on 
top. Small magnetic stirring bars were placed underneath the caps to mix the water phase. $\mathrm{C}_{2} \mathrm{H}_{2}$-saturated, distilled water $\left(200 \mu \mathrm{l}, 0^{\circ} \mathrm{C}\right)$ was injected through a vertical series of silicone-filled holes (i.d. $3 \mathrm{~mm}$ ) placed at $5 \mathrm{~mm}$ intervals along the side of the tubes. The water phase also received $\mathrm{C}_{2} \mathrm{H}_{2}$-saturated water and the final inhibitor concentration in the porewater and overlying water phase was about $10 \%$ of saturation (vol./vol.). The cores were incubated in the dark at in situ temperature using a thermostatted water bath. Incubation time was from 0 to $1.5 \mathrm{~h}$ and the cores were sacrificed in duplicate at 20 to $25 \mathrm{~min}$ intervals.

After incubation, the exact heights (volumes) of the water and sediment phases in the tubes were recorded. Twenty $\mathrm{ml}$ of the water phase was then transferred to a closed serum bottle ( $40 \mathrm{ml}$ volume) which was preevacuated to obtain atmospheric pressure after the water sample was injected. The bottle was shaken vigorously for 2 min to equilibrate the dissolved $\mathrm{N}_{2} \mathrm{O}$ with the gas phase. From the latter, duplicate $3 \mathrm{ml}$ gas samples were then taken to evacuated 'Venoject' tubes (Terumo Europe N.V., Leuven, Belgium). After the water samples were removed, the tubes were capped and shaken vigorously for 2 min to equilibrate the remaining $\mathrm{N}_{2} \mathrm{O}$ with the $20 \mathrm{ml}$ gas phase. Again, duplicate $3 \mathrm{ml}$ gas samples were transferred to evacuated 'Venoject' tubes. The gas samples were analysed for $\mathrm{N}_{2} \mathrm{O}$ on a Packard model 427 gas chromatograph equipped with a ${ }^{63} \mathrm{Ni}$ Electron Capture Detector held at $320^{\circ} \mathrm{C}$. A backflush system prevented $\mathrm{C}_{2} \mathrm{H}_{2}$ contamination of the detector and allowed for a short analysis time ( 3 min). Gases were separated on a $80 / 100$ mesh Porapak $\mathrm{Q}$ column (2 $\mathrm{m}$ long and $3.2 \mathrm{~mm}$ wide) operated at $80^{\circ} \mathrm{C}$. Pure $\mathrm{N}_{2}$ was used as the carrier gas at a flow rate of $15 \mathrm{ml} \mathrm{min}{ }^{-1}$.

In the headspace analysis, the volumetric solubility coefficients for $\mathrm{N}_{2} \mathrm{O}$ at various salinities and temperatures were used to correct for dissolved $\mathrm{N}_{2} \mathrm{O}$ in the equilibrations (Weiss \& Price 1980). Total $\mathrm{N}_{2} \mathrm{O}$ accumulation in the cores was the sum of $\mathrm{N}_{2} \mathrm{O}$ in the water sample and the suspension of sediment and water. The cores sacrificed at zero time were to correct for the in situ $\mathrm{N}_{2} \mathrm{O}$ content in the sediment. Denitrification rates (mmol $\mathrm{N} \mathrm{m}^{-2} \mathrm{~d}^{-1}$ ) were calculated as the mean of the $\mathrm{N}_{2} \mathrm{O}$ accumulation rates measured in 6 different cores. The detection limit for the assay was estimated to be $0.01 \mathrm{mmol} \mathrm{N} \mathrm{m}^{-2} \mathrm{~d}^{-1}$.

\section{RESULTS}

In Figs. 2 to 4 , which are presented in the following, the spring bloom of primary production (and sedimentation of algae) is identified from the rapid $\mathrm{NO}_{3}^{-}$deple- tion in the surface water (Fig. 3). The shaded area, which has been inserted in the figures, marks this period (about $1 \mathrm{mo}$ ) in the early spring.

\section{Hydrography}

During the sampling period surface water temperatures varied from about 0 to $18^{\circ} \mathrm{C}$ (Fig. 2, upper panel), which is typical of these shallow coastal waters; the bottom water temperature varied only from about 3 to $13^{\circ} \mathrm{C}$. Maximum temperature in the bottom water (and at the sediment surface) was reached in September. Thermal stratification was observed in both summer and winter; in summer, the temperature difference was up to $10 \mathrm{C}^{\circ}$ between surface and bottom waters. In winter, the difference between the warmer bottom water and the cooler surface water was about $3 \mathrm{C}^{\circ}$.

The stratification periods were interspersed by periods of mixing during the spring and fall as indicated by both temperature and salinity profiles. During mixing periods, the salinity was typically about $23 \%$, compared to an overall range of 13 to $27 \%$ for the surface water and 20 to $33 \%$ for the bottom water. During stratification, salinity of the bottom water was substantially higher than in the surface water (Fig. 2, lower panel). The mixing periods in both spring (early May in 1985 and mid-April in 1986) and fall (September to December) are also evident from the data.

\section{$\mathrm{O}_{2}$ and $\mathrm{NO}_{3}^{-}$concentrations in the water}

Oxygen in the water column was never seriously depleted during the investigation period; in the bottom water, the lowest $\mathrm{O}_{2}$ concentrations were about $130 \mu \mathrm{M}$ corresponding to about $50 \%$ air saturation (data not shown),

Maximum $\mathrm{NO}_{3}^{-}$concentrations (about $10 \mu \mathrm{M} \mathrm{NO}_{3}^{-}$) were found in the winter and minimum concentrations (below $1 \mu M$ ) in the summer (Fig. 3). The rapid $\mathrm{NO}_{3}^{-}$ consumption (marked by the shaded area in Fig. 3) in early spring (March-April) and the subsequent low concentrations (below $1 \mu M$ ) from mid-spring (AprilMay) to fall (October-November) were explained by assimilation in phytoplankton (primary production) in the area. During a year, $\mathrm{NO}_{2}^{-}$concentrations were never higher than $0.5 \mu M$ in the water column. Depletion of $\mathrm{NO}_{3}^{-}$in the surface water, which marked the period of the spring phytoplankton bloom, thus seemed to occur several weeks earlier in 1986 than in 1985. In both years, the water column was strongly stratified while $\mathrm{NO}_{3}^{-}$was being depleted (Fig. 2). 

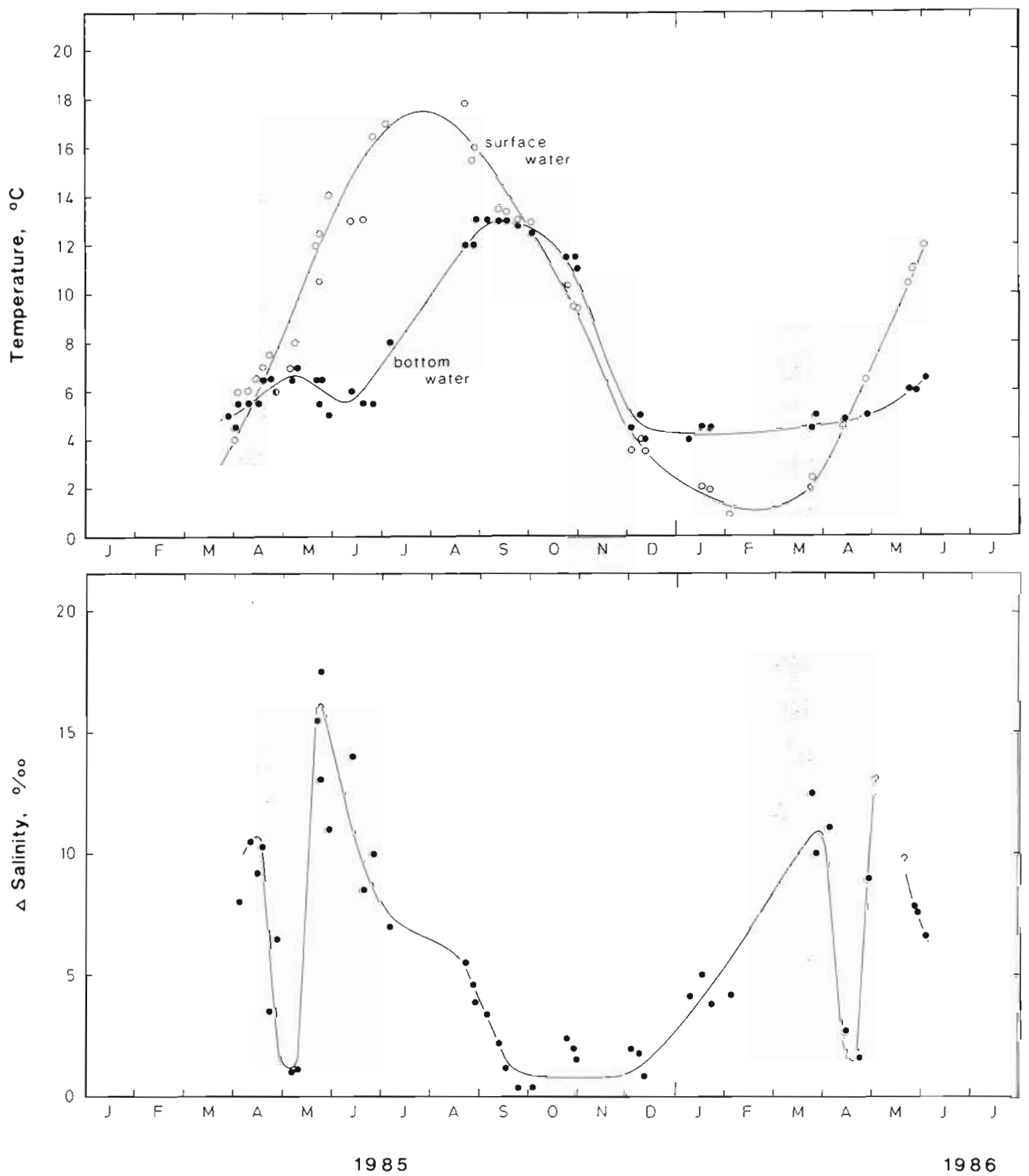

Fig. 2. Upper panel: Seasonal variation of temperature in surface water ( 1 ) and bottom water (•). Lower panel: Seasonal varıation of the difference in salinity between bottom water and surface water from Aarhus Bight. Shaded areas indicate sedimentation period for spring phytoplankton bloom

\section{Denitrification in the sediment}

Fig. 4 shows the seasonal variation of denitrification activity recorded at the 3 stations. A general pattern was discerned for the process: maximum activities in the spring were followed by decreasing denitrification in early summer and minima were reached in late summer and falj. Peak activities for Stn 10,16 and 22 were about $0.5,0.7$ and $1.0 \mathrm{mmol} \mathrm{N} \mathrm{m} \mathrm{m}^{-2} \mathrm{~d}^{-1}$ and minimum activities about $<0.05,0.05$ and $0.2 \mathrm{mmol} \mathrm{N} \mathrm{m}^{2} \mathrm{~d}^{-1}$. Standard errors of the mean ( $n=6$ ) are indicated; even if the core variability could be high, the seasonal and regional patterns of denitrification activity were still apparent.

\section{Sediment characteristics}

Table 1 characterizes the sediments at Stns 10,16 and 22 by density, water content, and organic content. Stns 16 and 22 had higher water content and contained 
Fig. 3. Seasonal variation of $\mathrm{NO}_{3}^{-}$concentration in the surface water from Aarhus Bight Shaded areas indicate sedimentation period for spring phytoplankton bloom

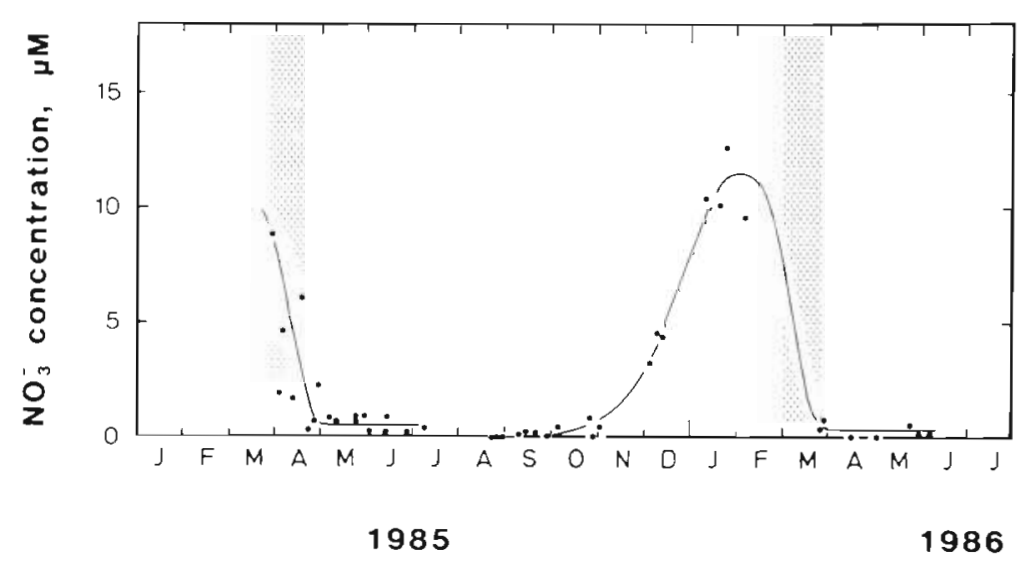

Fig. 4. Seasonal variation of denitrification activity in the sediment from Stns 10, 16 and 22 in Aarhus Bight. Standard errors of the mean $(n=6)$ are indicated. Shaded areas indicate sedimentation period for spring phytoplankton bloom

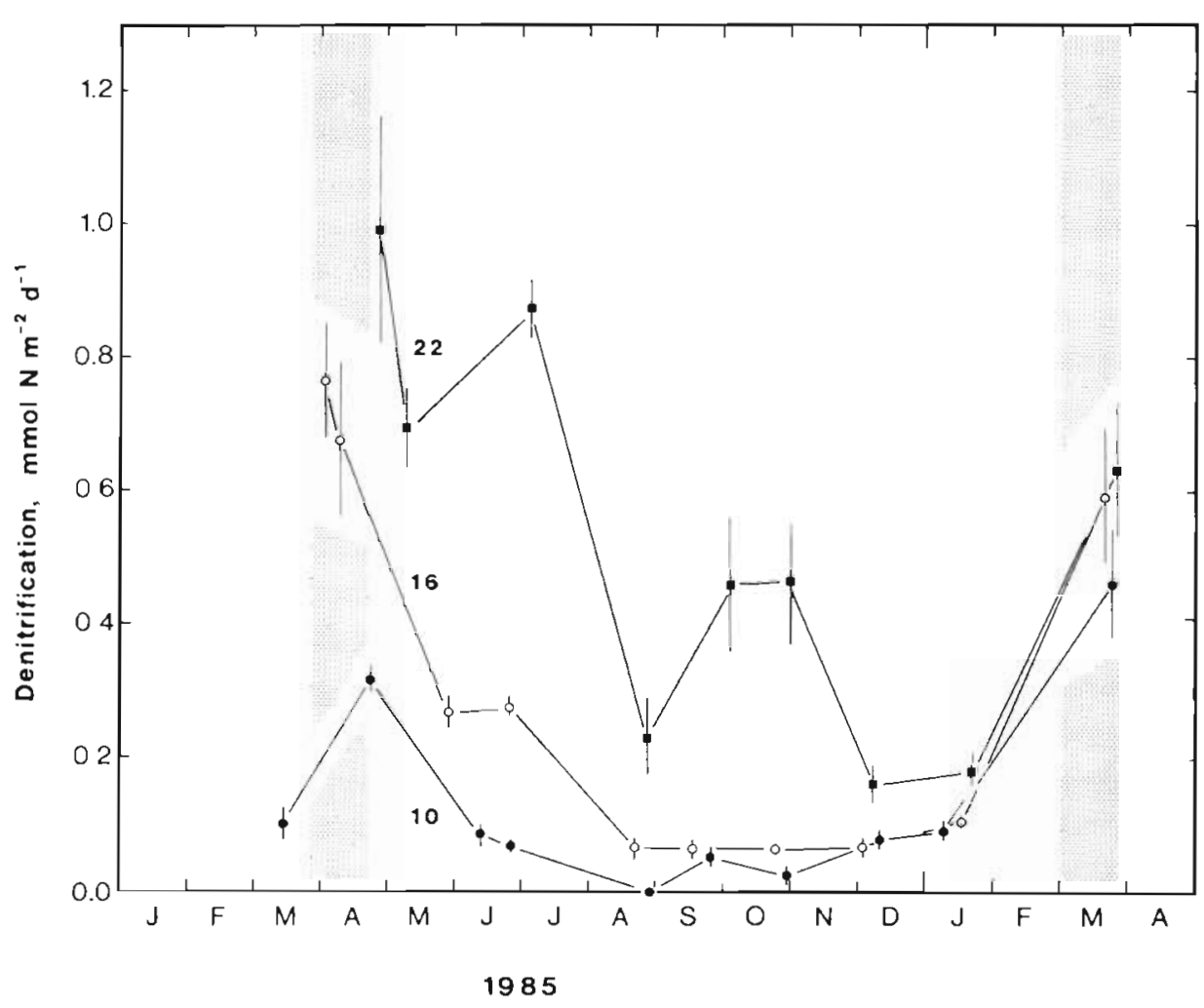

more fine-grained, organic material than Stn 10 sediment which had more clay and fine sand and less organic matter. Stn 22 had a particularly high organic content in the surface layer. During spring, all stations had a 1 to $2 \mathrm{~mm}$ thick, flocculent layer of organic material on the sediment surface, which was evidence for the rapid sedimentation of algal detritus in this period. The flocculent organic material was least pronounced at Stn 10, possibly reflecting lower net sedimentation at this location. The detritus layer sometimes appeared in patches within the 'Haps' cores; similar observations were made in a comparable type of coastal sediment by Christensen \& Kanneworff
(1986) This heterogeneity should explain some of the variability between cores from the same sampling event.

\section{DISCUSSION}

\section{Spring bloom and detritus sedimentation}

The spring bloom of phytoplankton resulted in the rapid $\mathrm{NO}_{3}^{-}$consumption in the surface waters during March-April. In these shallow waters, a large fraction of the spring production sinks quickly from the water 
Table 1. Sediment characteristics of Stns 10,16 and 22 in Aarhus Bight. Data are averages from 10 measurements over 16 mo in $1985-86$

\begin{tabular}{|ccccc|}
\hline Stn & $\begin{array}{c}\text { Depth } \\
\text { (cm) }\end{array}$ & $\begin{array}{c}\text { Density } \\
\left(\mathrm{g} \mathrm{cm}^{-3}\right)\end{array}$ & $\begin{array}{c}\text { Water content } \\
\text { (\% of wet wt.) }\end{array}$ & $\begin{array}{c}\text { Organic content } \\
\text { (\% of dry wt.) }\end{array}$ \\
\hline \multirow{4}{*}{10} & $0-1$ & 1.51 & 41 & 2.6 \\
& $1-2$ & 1.54 & 37 & 2.8 \\
& $2-3$ & 1.53 & 36 & 2.9 \\
& $3-4$ & 1.50 & 37 & 3.2 \\
& $4-5$ & 1.50 & 40 & 3.9 \\
& $0-1$ & 1.18 & 70 & 9.4 \\
16 & $1-2$ & 1.23 & 65 & 8.7 \\
& $2-3$ & 1.24 & 63 & 8.5 \\
& $3-4$ & 1.24 & 61 & 8.2 \\
& $4-5$ & 1.25 & 57 & 7.6 \\
& $0-1$ & 1.13 & 75 & 11.4 \\
22 & $1-2$ & 1.18 & 67 & 9.5 \\
& $2-3$ & 1.26 & 63 & 8.3 \\
& $3-4$ & 1.30 & 57 & 7.0 \\
$4-5$ & 1.34 & 51 & 5.8 \\
\hline
\end{tabular}

and reaches the bottom as easily-degradable detritus Rapid transport of phytoplankton may also be facilitated by the fact that the water column is stratified (Fig 2) and that grazing zooplankton are almost absent at this time of year (Smetacek 1985). Others have reported considerable increases in chlorophyll a phaeopigments and total organic matter in the upper 4 to $6 \mathrm{~mm}$ of sediment following the sedimentation of a spring bloom (Christensen \& Kanneworff 1986). In spite of the low temperature at this time, benthic metabolism has further been reported to increase immediately after sedimentation of a spring bloom (Graf et al. 1983 Meyer-Reil 1983, Kanneworff \& Christensen 1986). The sudden input of fresh organic material to the sediment surface may therefore trigger the onset of rapid mineralisation and release of $\mathrm{NH}_{4}^{+}$which in turn could be converted to $\mathrm{NO}_{3}$ by nitrifying bacteria (Kemp et al. 1982, Henriksen \& Kemp 1988). Alternatively, if the increased heterotrophic activity $\left(\mathrm{O}_{2}\right.$ consumption) results in decreased $\mathrm{O}_{2}$ penetration into the sediment, nitrification may actually be suppressed; bottom water $\mathrm{NO}_{3}^{-}$may in this case be important for denitrification following a spring bloom sedimentation. (Jensen et al. unpubl.)

\section{Denitrification in the sediment}

Both in spring and fall, sectioning of $\mathrm{C}_{2} \mathrm{H}_{2}$-treated cores showed that about $90 \%$ of the $\mathrm{N}_{2} \mathrm{O}$ accumulated in either the upper $1 \mathrm{~cm}$ segment or in the water phase of the sediments (data not shown). The data demonstrated that denitrification was dependent on either supply of $\mathrm{NO}_{3}^{-}$from the bottom water or $\mathrm{NO}_{3}^{-}$produc- tion (nitrification) in the $\mathrm{O}_{2}$-containing surface layer (Nishio et al. 1983, Jenkins \& Kemp 1984).

Various difficulties of the acetylene inhibition technique should be considered in measurements of such surface-located denitrification activity. Koike \& Sorensen (1988) have listed a number of potential drawbacks of the assay: (1) Physical disturbance of the surface sediment seems inevitable during the injection of inhibitor solution; this could alter the $\mathrm{O}_{2}$ and $\mathrm{NO}_{3}^{-}$ gradients or, in the worst case, wash the compounds completely out of the sediment. (2) Complete inhibition of $\mathrm{N}_{2} \mathrm{O}$ reduction may be difficult to obtain immediately after the inhibitor is applied, especially if the $\mathrm{C}_{2} \mathrm{H}_{2}$ is not rapidly and homogenously distributed during injection. (3) Complete $\mathrm{C}_{2} \mathrm{H}_{2}$ blockage of $\mathrm{N}_{2} \mathrm{O}$ reduction may be difficult to obtain at low $\mathrm{NO}_{3}^{-}$concentrations (Kaspar 1982, Oremland et al. 1984) or in the presence of sulfide (Tam \& Knowles 1979, Sørensen et al. 1987). (4) Blockage of bacterial $\mathrm{NH}_{4}^{+}$oxidation (nitrification) by $\mathrm{C}_{2} \mathrm{H}_{2}$ (Hynes \& Knowles 1982) could lower denitrification during the incubation due to a depletion of the $\mathrm{NO}_{3}^{-}$and $\mathrm{NO}_{2}^{-}$pools (Andersen et al. 1984).

The denitrification assay was always based on shortterm incubations of cores, and there was no significant difference between the rates determined from the first cores (sacrificed after 20 to $25 \mathrm{~min}$ ) and those recorded in the last cores (sacrificed after $1.5 \mathrm{~h}$ ). Therefore, we argue that a constant level of inhibition of $\mathrm{N}_{2} \mathrm{O}$ reduction was obtained from the beginning of the incubation period. The constant rate of $\mathrm{N}_{2} \mathrm{O}$ accumulation also indicated that the change of the $\mathrm{NO}_{3}^{-}$concentrations with time did not significantly affect the denitrification rate, even if nitrification was inhibited and the $\mathrm{NO}_{3}^{-}$ pool decreased during the incubation. We conclude that the variation of denitrification, which was 5- to $10-$ fold on a seasonal scale and 2- to 5 -fold between the stations, was correct, in spite of the potential drawbacks of the acetylene inhibition technique and the apparent heterogeneity of the sediment.

\section{Seasonal variation of denitrification}

The steep increase of denitrification in the sediments in early spring seemed to be directly related to sedimentation of the preceding bloom of phytoplankton. The minor increase in temperature could hardly explain the rapid increase of denitrification between February and April. Most likely, the process was stimulated by the supply of fresh phytodetntus, which served as a suitable organic substrate. It was uncertain, however, if the sedimentation also stimulated nitrification due to increased $\mathrm{NH}_{4}^{+}$release or if nitrification was actually suppressed during this period. In the latter case, the $\mathrm{NO}_{3}^{-}$demand for the denitrification maximum 
must partly be met by the pool of $\mathrm{NO}_{3}^{-}$in the bottom water. The low denitrification in the summer and fall must be a result of lesser sedimentation and limitation by $\mathrm{NO}_{3}^{-}$We did not measure nitrification in the present investigation, but earlier measurements using sediment from the same area have suggested that this activity is indeed relatively low during summer (Hansen et al. 1981, Henriksen et al. 1981). Further, $\mathrm{NO}_{3}^{-}$ was almost absent in the bottom water during summer and early fall (data not shown).

\section{Regional variation of denitrification}

The data reported here comprise one of the first detailed seasonal records of the annual pattern of denitrification in coastal marine sediments. In Norsminde Fjord, which is a $\mathrm{NO}_{3}^{-}$-polluted estuary adjacent to Aarhus Bight, annual denitrification rates were 1800 mmol $\mathrm{N} \mathrm{m}^{-2} \mathrm{yr}^{-1}$ for the inner estuary (Jørgensen \& Sorensen 1988) and $450 \mathrm{mmol} \mathrm{Nm}^{-2} \mathrm{yr}^{-1}$ for the outer estuary (Jørgensen \& Sørensen 1985). Based on the rate measurements shown in Fig. 4, the annual denitrification activities in Aarhus Bight were about 35, 70 and $180 \mathrm{mmol} \mathrm{N} \mathrm{m} \mathrm{yr}^{-1}$ at Stns 10, 16 and 22 , respectively. An earlier indirect estimate of denitrification in the same area gave $130 \mathrm{mmol} \mathrm{N} \mathrm{m}^{-2} \mathrm{yr}^{-1}$, based on 2 cruises in July and November (Blackburn \& Henriksen 1983). Seitzinger et al. (1984) measured $\mathrm{N}_{2}$ emission (denitrification) in 3 sediments from Narragansett Bay ( 2 to 5 occasions during 1 yr of investigation); denitrification rates ranged from 0.2 to $2.8 \mathrm{mmol} \mathrm{N} \mathrm{m}^{-2}$ $\mathrm{d}^{-1}$, a range which is somewhat higher than reported here for the Aarhus Bight $<0.05$ to $1.0 \mathrm{mmol} \mathrm{N} \mathrm{m}^{-2}$ $\mathrm{d}^{-1}$ ).

As for the seasonal variation, the regional differences in denitrification could relate directly to the sedimentation of the phytoplankton bloom in early spring. The increasing level of activity found at Stns 10,16 and 22, (in this order) was likely to be a result of a similar increase in the sedimentation rate for organic detritus. It was evident that Stns 10,16 and 22 (in this order) had an increasing organic content in the surface sediment (0 to $5 \mathrm{~cm}$ depth), and that Stn 22 (and to a minor extent Stn 16) had a particularly high organic content in the uppermost $\mathrm{cm}$.

It was recently shown from large experimental enclosures that a higher nutrient $\left(\mathrm{NH}_{4}^{+}\right)$loading in the water may lead to higher phytoplankton production and increased denitrification in the sediment (Seitzinger \& Nixon 1985). The in situ activities measured in this study also suggest that denitrification increases with higher sedimentation and organic loading of the sediment. It is evident, however, that a continued and heavy organic sedimentation may eventually stimulate heterotrophic metabolism to such an extent that availability of $\mathrm{O}_{2}$ for nitrification will be reduced or disappear completely. In case the water column is an insignificant $\mathrm{NO}_{3}^{-}$source, it is therefore of prime importance for the maintenance of denitrification in the sediment that nitrification occurs throughout the season.

Acknowledgements. We are indebted to Hans Jensen on board the 'Genetica' for helpful assistance during sampling and to Karen S. Christiansen, Jette Gissel, Preben G. Sørensen and Tove Wiegers for their skillful technical assistance. Thanks are also due to Kirsten S. Jørgensen for many helpful discussions and to Anni Jensen for typing the manuscript. This study was supported by the National Agency for Environmental Protection under the Danish Ministry of the Environment (J. no. M 85-21-66) and by the Danish Natural Science Research Council (J. no. 11-5469)

\section{LITERATURE CITED}

Andersen, T K., Jensen, M. H., Sorensen, J. (1984). Diurnal variation of nitrogen cycling in coastal, marine sediments. I. Denitrification. Mar Biol. 83: 171-176

Armstrong, F. A., Stearns, C. R., Strickland, J. D. (1967). The measurement of upwelling and subsequent biological processes by means of the Technicon Autoanalyzer and associated equipment. Deep Sea Res. 14: 381-389

Blackburn, T. H., Henriksen, K. (1983). Nitrogen cycling in different types of sediment from Danish waters. Limnol. Oceanogr 28: 477-493

Boynton, W. R., Kemp, W. M., Osborne, C. G. (1980). Nutrient fluxes across the sediment-water interface in the turbid zone of a coastal plain estuary. In: Kennedy, $\mathrm{V}$ S. (ed.) Estuarine perspectives. Academic Press, New York, p. 93-109

Christensen, H., Kanneworff, E. (1986). Sedimentation of phytoplankton during a spring bloom in the Gresund. Ophelia 26: 109-122

Graf, G., Schulz, R., Peinert, R., Meyer-Reil, L.-A. (1983). Benthic response to sedimentation events during autumn to spring at a shallow-water station in the Western Kiel Bight. I. Analysis of processes on a community level. Mar. Biol. 77: 235-246

Hansen, J. I., Henriksen, K., Blackburn, T. H. (1981). Seasonal distribution of nitrifying bacteria and rates of nitrification in coastal marine sediments. Microb. Ecol. 7: 297-304

Henriksen, K., Hansen, J. I., Blackburn, T. H. (1981). Rates of nitrification, distribution of nitrifying bacteria and nitrate fluxes in different types of sediment from Danish waters. Mar. Biol. 61: 299-304

Henriksen, K., Kemp, W. M. (1988). Nitrification in estuarine and coastal marine sediments. In: Blackburn, T. H., Sørensen, J. (eds.) Nitrogen cycling in coastal marine environments. John Wiley \& Sons, Chichester, p. 207-249

Hynes, R. K., Knowles, R. (1982). Effect of acetylene on autotrophic and heterotrophic nitrification. Can. J. Microbiol. 28: $334-340$

Jenkins, M. C., Kemp, W. M. (1984). The coupling of nitrification and denitrification in two estuarine sediments. Limnol. Oceanogr. 29: 609-619

Jorgensen, B. B., Sorensen, J. (1985). Seasonal cycles of $\mathrm{O}_{2}$ $\mathrm{NO}_{3}^{-}$and $\mathrm{SO}_{4}^{2-}$ reduction in estuarine sediments: the significance of an $\mathrm{NO}_{3}^{-}$reduction maximum in spring. Mar. Ecol. Prog. Ser 24: 65-74 
Jergensen, K. S., Serensen, J. (1988). Two annual maxima of nitrate reduction and denitrification in estuarine sediment (Norsminde Fjord, Denmark). Mar. Ecol. Prog. Ser. 48: $147-154$

Kanneworff, E., Christensen, H. (1986). Benthic community respiration in relation to sedimentation of phytoplankton in the Øresund. Ophelia 26: 269-284

Kanneworff, E., Nicolaisen, W. (1973). The 'Haps', a frame supported bottom corer. Ophelia 10: 119-128

Kaspar, H. F. (1982). Denitrification in marine sediment: measurement of capacity and estimate of in situ rate. Appl. environ. Microbiol. 43: 522-527

Kaspar, H. F., Asher, R. A., Boyer, I. C. (1985). Microbial nitrogen transformations in sediments and inorganic nitro. gen fluxes across the sediment-water interface on the South Island West Coast, New Zealand. Estuar. coast. Shelf Sci. 21: 245-255

Kemp, W M., Wetzel, R. L., Boynton, W. R., D'Elia, C. F., Stevenson, J. C. (1982). Nitrogen cycling and estuarine interfaces: some concepts and research directions. In: Kennedy, V. S. (ed.) Estuarine comparisons. Academic Press, New York, p. 209-230

Koike, I., Sørensen, J. (1988). Nitrate reduction and denitrification in marine sediments. In: Blackburn, T. H., Sørensen, J. (eds.) Nitrogen cycling in coastal marine environments. John Wiley \& Sons, Chichester, p. 251-273

Maybeck, M. (1982). Carbon, nitrogen and phosphorus transport by world rivers. Am. J. Sci. 282: 401-450

Meyer-Reil, L.-A. (1983). Benthic response to sedimentation events during autumn to spring at a shallow water station in the Western Kiel Bight. II. Analysis of benthic bacterial populations. Mar. Biol. 77: 247-256

Nishio, T., Koike, I, Hattori, A. (1983). Estimates of denitrification and nitrification in coastal and estuarine sediments. Appl. environ. Microbiol. 45: 444-450

Nixon, S. W. (1981). Remineralization and nutrient cycling in coastal marine ecosystems. In: Neilson, B. J., Cronin, L. E. (eds.) Estuaries and nutrients. Humana Press, Clifton, New Jersey, p. 111-138
Oremland, R. S., Umberger, C., Culbertson, C. W., Smith, R. L. (1984). Denitrification in San Francisco Bay sediments. Appl. environ. Microbiol. 47: 1106-1112

Seitzinger, S. (1987). Nitrogen biochemistry in an unpolIuted estuary: the importance of benthic denitrification. Mar. Ecol. Prog. Ser 41. 177-186

Seitzinger, S. P., Nixon, S. W. (1985). Eutrophication and the rate of denitrification and $\mathrm{N}_{2} \mathrm{O}$ production in coastal marine sediments. Limnol. Oceanogr. 30: 1332-1339

Seitzinger, S. P., Nixon, S. W., Pilson, M. E. Q. (1984). Denitrification and nitrous oxide production in a coastal marine ecosystem. Limnol. Oceanogr. 29: 73-83

Smetacek, V (1985). Role of sinking in diatom life-history cycles: ecological, evolutionary and geological significance. Mar. Biol. 84; 239-251

Smith, C. J., DeLaune, R. D., Patrick, Jr., W. H. (1985). Fate of riverine nitrate entering an estuary: 1 . Denitrification and nitrogen burial. Estuaries 8: 15-21

Strickland, J. D., Parsons, T. R. (1972). A practical handbook of seawater analysis, 2nd edn. Bull. Fish. Res. Bd Can. 167

Sørensen, J. (1978). Denitrification rates in a marine sediment as measured by the acetylene inhibition technique. Appl. environ. Microbiol. 36: 139-143

Sørensen, J. (1984). Seasonal variations and control of oxygen, nitrate and sulfate respiration in coastal marine sediments. In: Klug, M. J., Reddy, C. A. (eds.) Current perspectives in microbial ecology, Am. Soc. Microbiol., Washington D. C., p. $447-453$

Sørensen, J., Rasmussen, L. K., Koike, I. (1987). Micromolar sulfide concentrations alleviate acetylene blockage of nitrous oxide reduction by denitrifying Pseudomonas fluorescens. Can. J. Microbiol. 33: 1001-1005

Tam, R.-Y., Knowles, R. (1979). Effects of sulfide and acetylene on nitrous oxide reduction by denitrifying bacteria Can. J. Microbiol. 25: 1133-1138

Weiss, R. F., Price, B. A. (1980). Nitrous oxide solubility in water and seawater. Mar. Chem. 8: 347-359 